\title{
Literature Review: Biological Monitoring of Occupational Tetrachloroethylene Exposure in Workers
}

\section{Kajian Pustaka: Biomonitoring pada Pekerja yang Terpajan Tetrakloroetilena}

\author{
Dina Tri Amalia ${ }^{1}$, Muhammad Ilyas ${ }^{2}$ \\ ${ }^{1}$ Occupational Medicine Specialist Programme, Faculty of Medicine, Universitas Indonesia, Indonesia \\ ${ }^{2}$ Division of Occupational Medicine, Department of Community Medicine, Faculty of Medicine, Universitas \\ Indonesia, Indonesia \\ 1,2Jalan Pegangsaan Timur No.16, Menteng, Central Jakarta 10320 Indonesia
}

\begin{abstract}
Introduction: One of the most common chlorinated solvents in the world is tetrachloroethylene (TCE) because it is widely used in various industries. Exposure to tetrachloroethylene can cause health problems so biological monitoring is necessary to do. The aim of this research is to assess which one is more feasible to use among the various types of biological monitoring for tetrachloroethylene exposure, based on the evidence-based literature. Methods: The literature searching was performed via electronic databases from PubMed, Scopus, and Proquest. The keywords used were "biological monitoring", "biomonitoring", "tetrachloroethylene", "perchloroethylene", "work" and "occupation". The articles were chosen based on the given inclusion and exclusion criteria. Selected articles were then critically appraised. Results: Initially 29 papers were collected, but only 6 cross-sectional articles were selected after the screening process and manual searching. Based on the selected evidence-based literatures, statistically meaningful associations were found between tetrachloroethylene exposure and tetrachloroethylene in blood in pre- and end-of-shift, in urine at end of shift, and in exhaled air at end-of-shift. Moreover, micronucleus frequency and DNA damages between dry cleaning workers and the controls differed significantly. Conclusion: The level of tetrachloroethylene in blood, urine, and exhaled air becomes an appropriate biological exposure index for assessing tetrachloroethylene exposure in dry-cleaning workers. In Indonesia, biomonitoring that is more feasible to be implemented is micronucleus frequency evaluation from buccal mucosal epithelial smears since it is a simpler, faster, and less expensive procedure.
\end{abstract}

Keywords: biological monitoring, biomonitoring, occupational exposure, tetrachloroethylene

\section{ABSTRAK}

Pendahuluan: Tetrakloroetilena adalah salah satu pelarut terklorinasi yang memiliki peranan penting di seluruh dunia karena banyak digunakan di berbagai industri. Paparan tetrakloroetilena dapat menyebabkan gangguan kesehatan sehingga perlu dilakukan biomonitoring. Tujuan dari penelitian ini adalah untuk mengetahui biomonitoring yang paling andal dan berpotensi digunakan berdasarkan tinjauan literatur berbasis bukti. Metode: Pencarian literatur dilakukan melalui database elektronik dari PubMed, Scopus, dan Proquest. Kata kunci yang digunakan adalah biological monitoring, biomonitoring, tetrachloroethylene, perchloroethylene, work and occupation. Pemilihan artikel dilakukan dengan menggunakan kriteria inklusi dan eksklusi yang ditentukan. Artikel terpilih selanjutnya dilakukan telaah kritis. Hasil: Pada awalnya diperoleh 29 artikel, namun setelah melalui proses seleksi dan pencarian manual diperoleh enam artikel cross sectional. Berdasarkan literatur berbasis bukti yang telah dipilih diketahui bahwa secara statistik terdapat hubungan yang signifikan antara paparan tetrakloroetilena dan tetrakloroetilena dalam darah akhir shift dan pre-shift, tetrakloroetilena dalam urin akhir shift, dan tetrakloroetilena pada udara ekshalasi akhir shift. Terdapat perbedaan yang signifikan antara frekuensi mikronukleus dan kerusakan DNA antara pekerja dry cleaning dan kontrol. Simpulan: Konsentrasi tetrakloroetilena dalam darah, urin dan udara ekshalasi menjadi indeks pajanan biologis yang memadai yang dapat diterapkan untuk mengevaluasi pajanan tetrakloroetilena pada pekerja dry cleaning. Di Indonesia, pemeriksaan yang lebih memungkinkan untuk diterapkan adalah pemeriksaan frekuensi mikronukleus pada sediaan apusan epitel mukosa bukal karena merupakan prosedur yang lebih mudah, cepat dan murah.

Kata kunci: biomonitoring, monitoring biologi, pajanan pekerjaan, tetraktloroetilena

\section{Corresponding Author:}

Dina Tri Amalia

Email: dinatriamalia@gmail.com

Telephone: +6282379234090

(C2021 IJOSH All right reserved. Open access under CC BY NC-SA license doi:10.20473/ijosh.v10i2.2021.280-288 Received February 10, 2021, received in revised form April 21, 2021, Accepted May 28, 2021, Published: August 2021 


\section{INTRODUCTION}

Tetrachloroethylene $\left(\mathrm{C}_{2} \mathrm{C}_{14}\right)$ is a colorless, non-flammable, and unstable chlorocarbon group (Julianti et al., 2019). Tetrachloroethylene is also known as perchloroethylene or PCE or Perc. It has been manufactured commercially since the 19th century and has become one of the most essential chlorinated solvents worldwide (Vlaanderen et al., 2014). This substance is widely used in many industries including metal clean $\neg$ ing, dry cleaning, mining equipment cleaning, coal testing, film cleaning and duplicating, printing industries, textile industries, and chemical synthesis processes (Gold et al., 2008; Barton, 2014; IARC, 2014).

Tetrachloroethylene is quickly released into the air and inhaled due to its very unstable nature. It may also be absorbed through the skin and mouth. Acute exposure to tetrachloroethylene can induce health problems such as eye irritation, upper airway problems, renal abnormalities, and nervous system dysfunctions such as headaches, sleep disorder and also fainting, all of which are common symptoms. Meanwhile, liver disease, kidney problems, immune disorders, hematologic diseases, and reproductive system defects are the most common effects of chronic tetrachloroethylene exposure in humans (Cichocki et al., 2016; Julianti et al., 2019). Exposure to tetrachloroethylene has also been linked to cancer. According to the International Agency for Research on Cancer (IARC), "tetrachloroethylene is listed as category 2A (probable human carcinogen)" (Barton, 2014; IARC, 2014).

Biological monitoring (biomonitoring) is used to secure individuals from the potential health hazards of dangerous chemicals in the workplace such as tetrachloroethylene. Regardless of the route of exposure, this method can detect the intensity of worker exposure (Kawai, Sakurai and Ikeda, 2018). Workers' health must be monitored by a multidisciplinary program that combines occupational hygiene, pharmacy, and nursing. Workers exposed must be evaluated through biological monitoring program using biomarkers regularly to assess and track changes in the onset of adverse health effects (Hopf et al., 2019).

The urinary excretion of the primary tetrachloroethylene metabolites, trichloroacetic acid level in blood, trichloroacetic acid in urine, and also trichloroethanol in urine have all been suggested in the past for the biological monitoring of tetrachloroethylene exposure. The level of tetrachloroethylene in end-exhaled air and blood are the biological exposure indices (BEIs) suggested by the American Conference of Governmental Industrial Hygienists (ACGIH) at the moment. Tetrachloroethylene concentrations in urine have also been suggested as a biological index of exposure (Modenese et al., 2019).

In addition to biological monitoring of tetrachloroethylene exposure, another test that can be used for evaluation is biomonitoring of effect. Tetrachloroethylene is known to cause mutagenic and carcinogenic effects. Several tests that have been done to assess genetic damage due to tetrachloroethylene exposure include nuclear anomaly tests. Micronucleus is known as an easy way to see whether there has been a genetic damage caused by tetrachloroethylene exposure. Sister chromatid exchange frequency, oxidative deoxyribonucleic acid (DNA) damage and chromosomal abnormalities have all been related to tetrachloroethylene exposure in a number of studies (Tucker et al., 2011). This study's goal is to evaluate which one is more feasible to use among the various types of biological monitoring for tetrachloroethylene exposure, based on the evidencebased literature.

\section{METHODS}

The literature search was performed via electronic databases from PubMed, Scopus, and Proquest. Allrelevant articles were searched in these databases published from 2011 to January 9 th 2021. The keywords used were biological monitoring, biomonitoring, tetrachloroethylene, perchloroethylene, work and occupation. The screening process was based on the predetermined criteria. The inclusion criteria of this searching strategy were systematic review, metaanalysis, cohort study, case-control study, crosssectional study, occupational population and tetrachloroethylene exposure. Meanwhile, the exclusion criteria were inaccessible articles, articles which were not in English, and statistical value data which were not available. Furthermore, hand searching was done in addition to the electronic database. The article selection strategy can be seen in Figure 1. Six cross-sectional articles remained for appraisal. The papers that were chosen were then appraised using relevant criteria by "the Oxford Center for Evidence-Based Medicine for diagnostic 
Table 1. Search Strategy Using Keywords

\begin{tabular}{llc}
\hline \multicolumn{1}{c}{ Database } & \multicolumn{1}{c}{ Keyword } & Hit \\
\hline PubMed & $\begin{array}{l}\text { ((biological monitoring OR biomonitoring) AND (tetrachlorethylene OR perchlorethylene)) AND } \\
\text { (work* OR occupation*) }\end{array}$ & 49 \\
Scopus & $\begin{array}{l}\text { (((biological monitoring OR biomonitoring) AND (tetrachlorethylene OR perchlorethylene)) AND } \\
\text { (work* OR occupation*)) }\end{array}$ & 66 \\
Proquest & $\begin{array}{l}\text { (biological monitoring OR biomonitoring) AND (tetrachlorethylene OR perchlorethylene) AND } \\
\text { worker }\end{array}$ & 284 \\
\hline
\end{tabular}

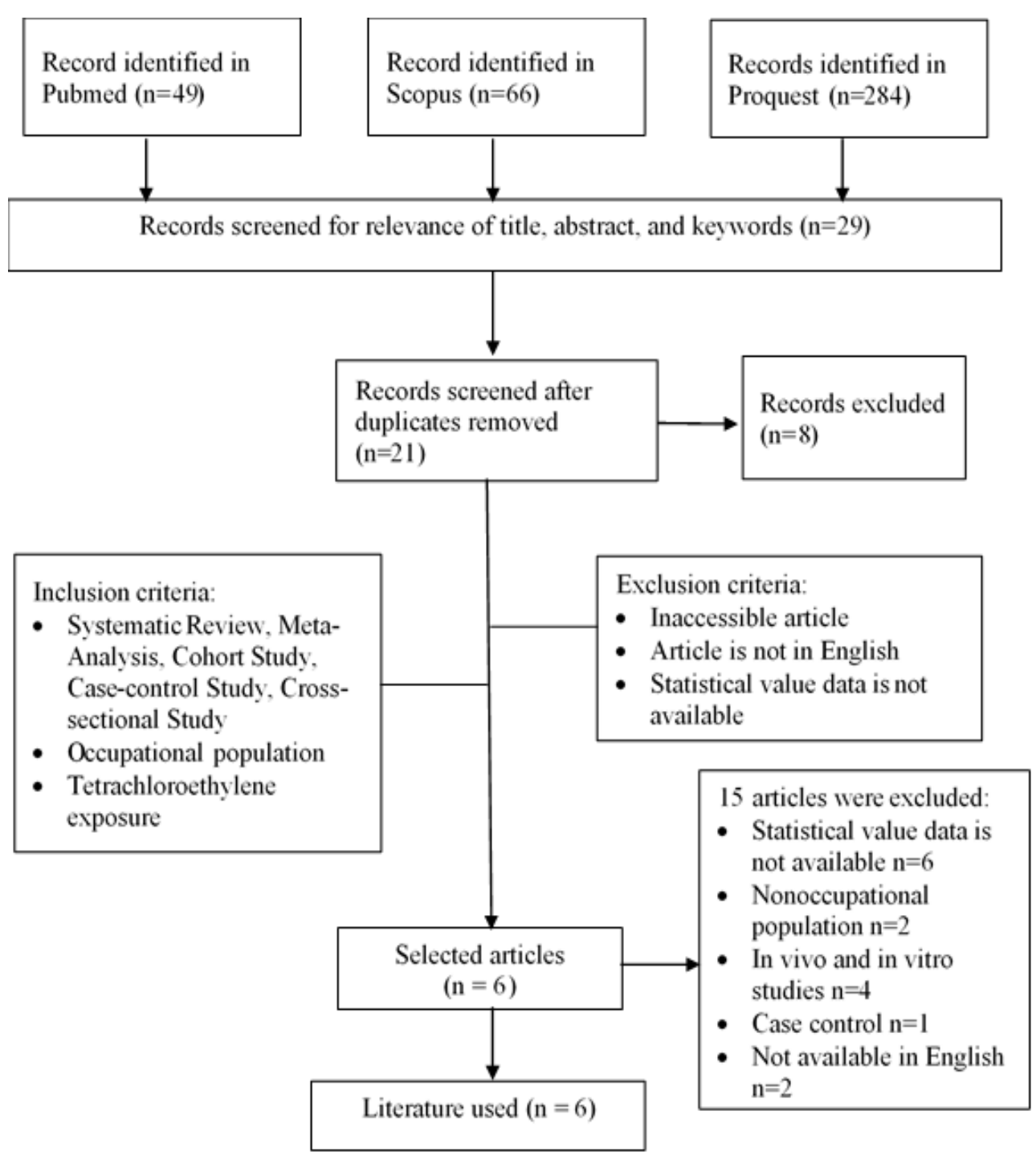

Figure 1. The Process of Article Selection

study" (OCEBM, 2021). The results of the appraisal are presented in Table 2.

\section{RESULTS}

Based on the criteria for diagnostic study by Oxford Center, it is known that all articles that were reviewed critically in this study were included in the level of evidence 3, namely "non-consecutive studies, or studies without consistently applied reference standards" (OCEBM, 2021). The study by Modenese et al. (2019) used non-invasive biological indices to assess occupational tetrachloroethylene exposure in the dry cleaning industry. Personal sampling was used to determine environmental exposure of 60 workers in 21 dry cleaning shops 
Table 2. Critical Appraisal Checklist for Diagnostic Study

\begin{tabular}{|c|c|c|c|c|c|c|c|c|}
\hline \multirow[b]{2}{*}{ Articles } & \multirow[b]{2}{*}{$\begin{array}{l}S \underset{\text { Design }}{\mathbf{t}} \mathbf{u} \mathbf{d} \\
\mathbf{y}\end{array}$} & \multirow[b]{2}{*}{ 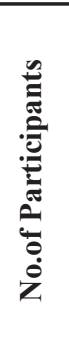 } & \multicolumn{3}{|c|}{ Validity } & \multirow[b]{2}{*}{ 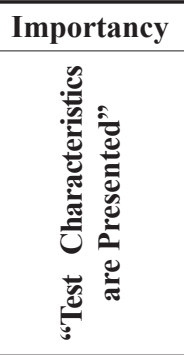 } & \multirow[b]{2}{*}{ 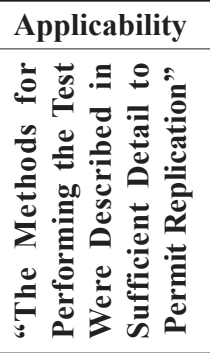 } & \multirow[b]{2}{*}{$\begin{array}{l}\text { Level of } \\
\text { Evidence }\end{array}$} \\
\hline & & & 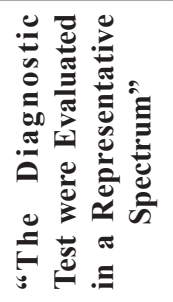 & 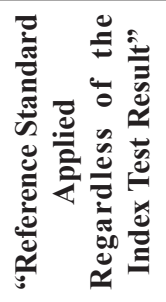 & 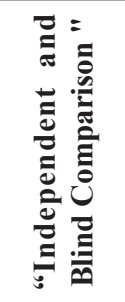 & & & \\
\hline $\begin{array}{l}\text { "Evaluation of } \\
\text { Occupational Exposure } \\
\text { to Perchlorethylene } \\
\text { in a Group of Italian } \\
\text { Dry Cleaners using } \\
\text { NonInvasive Exposure } \\
\text { Indices" (Modenese et } \\
\text { al., 2019) }\end{array}$ & $\begin{array}{l}\text { Cross- } \\
\text { sectional }\end{array}$ & 60 & Yes & No & Unclear & Yes & Yes & 3 \\
\hline $\begin{array}{l}\text { "The Effect of } \\
\text { Perchloroethylene } \\
\text { (PCE) Exposure } \\
\text { Toward Frequency } \\
\text { of Micronucleus } \\
\text { Formation in Buccal } \\
\text { Mucosal Ephitelia } \\
\text { of Dry Cleaning } \\
\text { Employees" } \\
\text { (Julianti et al., 2019) }\end{array}$ & $\begin{array}{l}\text { Cross- } \\
\text { sectional }\end{array}$ & 44 & Yes & No & Unclear & Yes & Yes & 3 \\
\hline $\begin{array}{l}\text { "Primary DNA } \\
\text { Damage in Dry } \\
\text { Cleaners with } \\
\text { Perchloroethylene } \\
\text { Exposure" } \\
\text { (Azimi et al., 2017) }\end{array}$ & $\begin{array}{c}\text { Cross- } \\
\text { sectional }\end{array}$ & 59 & Yes & No & Yes & Yes & Yes & 3 \\
\hline $\begin{array}{l}\text { "Use of exhaled } \\
\text { air as an improved } \\
\text { biomonitoring } \\
\text { method to assess } \\
\text { perchloroethylene } \\
\text { short-term exposure" } \\
\text { (Dias et al., 2017) }\end{array}$ & $\begin{array}{l}\text { Cross- } \\
\text { sectional }\end{array}$ & 25 & Yes & No & Unclear & Yes & Yes & 3 \\
\hline $\begin{array}{l}\text { "Biomonitoring Study } \\
\text { of Dry Cleaning } \\
\text { Workers Using } \\
\text { Cytogenetic Tests and } \\
\text { the Comet Assay" } \\
\text { (Everatt et al., 2013) }\end{array}$ & $\begin{array}{l}\text { Cross- } \\
\text { sectional }\end{array}$ & 59 & Yes & No & Yes & Yes & Yes & 3 \\
\hline $\begin{array}{l}\text { "Biological monitoring } \\
\text { of exposure to } \\
\text { perchloroethylene in } \\
\text { dry cleaning workers" } \\
\text { (Macca et al., 2012) }\end{array}$ & $\begin{array}{l}\text { Cross- } \\
\text { sectional }\end{array}$ & 71 & Yes & No & Unclear & Yes & Yes & 3 \\
\hline
\end{tabular}

in North Italy. As biological exposure indices, PCE in exhaled alveolar air, PCE urinary concentration, and trichloroacetic acid urinary concentration were measured. The findings of this study revealed that PCE levels in the environment were less than $10 \%$ of occupational limits in all samples. The biological markers with the highest correlation with tetrachloroethylene in environment $(\mathrm{r}=0.81)$ were calculated in samples obtained at the end of shift. Tetrachloroethylene in alveolar also had a high correlation $(\mathrm{r}=0.66)$, while trichloroacetic acid in urine or TCAu calculated at the end of shift had a lower correlation $(\mathrm{r}=0.32)$. 
Based on the study by Modenese et al. (2019), "tetrachloroethylene in urine can be suggested as a valid, noninvasive, and easily reliable exposure index for assessing tetrachloroethylene exposure at the low levels used in dry cleaners nowadays". PCEu has also emerged as a potential alternative to the invasive blood sampling used to assess PCE blood concentration. The number of dry-cleaning shops and employees participated in this study was relatively small, and the exposure was measured for only one day in 1 working week. According to data gathered during Occupational Health and Safety (OHS) experts' worksite inspections, the tasks conducted in dry cleaning were reasonably close on different working days.

The study by Julianti et al. (2019) conducted the evaluation of buccal mucosal smears on 44 workers consisting of 22 workers exposed to tetrachloroethylene and 22 subjects who were not exposed to tetrachloroethylene. The aim of this study was to see how tetrachloroethylene exposure affected the frequency of micronuclei in the mucosal epithelium of dry cleaning workers' buccal in Banyumas. Buccal cells are the first line of defense against inhalation or ingestion carcinogens, and they may convert proximate carcinogens to reactive items.

Micronuclei are abnormal cell nuclei that develop during the mitosis phase as a result of chromosome damage. Micronucleus becomes a biomarker that can be identified as a result of genotoxic material exposure and a warning of carcinogenesis's initial process. Using spatula, epithelial cells in buccal were collected, smeared on an object glass, and stained with Giemsa. A light microscope was used to quantify micronuclear frequencies per 1000 cells. It was found that the frequency of micronuclei differed between the two groups $(p=0.000)$ in this analysis. The frequency of micronucleus formation was also associated with the length of time spent at work and age (Julianti et al., 2019).

The study by Azimi et al. (2017), furthermore, compared subjects who used tetrachloroethylene at work with those who did not use tetrachloroethylene to see how much primary DNA exposure they had. The impact of exposure modifying factors like personal protective equipment (PPE), perceived danger, and recorded safe behaviors on observed DNA damage was also investigated. The participants in this study were 59 exposed and non-exposed employees from Yazd, Iran. All of the 33 staff who were exposed had worked in dry cleaning shops for at least three months. A peripheral blood sample was taken and examined under fluorescent microscope $(400 \times)$. Image analysis used open comet software, and all of the biological testing was done in a single laboratory.

Based on Azimi et al. (2017), "primary DNA damage to leukocytes in dry cleaners was found to be relatively high. The exposed group's median tail weight, percent DNA in tail, and tail moment were all significantly higher than the non-exposed group's". The limitation of this study is they did not measure exposure to see whether there was a dose-response relationship. The authors claimed that like a previous study's finding, they used similar dry cleaning machines and techniques around workshops, so that comparison of results seemed reasonable (Azimi et al., 2017).

Moreover, the study by Dias et al. (2017) showed the use of exhaled air obtained at the end of shift as a biomonitoring way of assessing perchloroethylene exposure in the environment and at work. Cold fiber solid-phase microextraction was used as a sampling technique to simulate the air matrix in the established method. In addition, gas chromatography with mass spectrometry was used for the analysis. The developed methods were tested at 27 different locations in Belo Horizonte, Brazil, including dry cleaners, laboratory, automotive and electroplating industry.

Based on the findings, alveolar air was known to be an appropriate marker for assessing exposure to tetrachloroethylene in workplace, as shown by the high association observed between environment and alveolar air $(\mathrm{r}=0.930)$. Moreover, it is known that exhaled air was a promising parameter for biomonitoring and evaluating environmental and occupational exposure, according to the findings of this report (Dias et al., 2017).

The study by Everatt et al. (2013) claimed that an increase in micronucleus and DNA damage was observed after the occupational exposure to PCE levels was below the occupational exposure limit. Among dry cleaners and the controls, there were no significant differences in the incidence of chromosome aberrations. The aim of this study was to see how genotoxic PCE exposure in dry cleaners worked. A total of 59 people took part in this study (30 workers, 29 controls). In peripheral blood lymphocytes, the genotoxic impact was assessed by looking at micronuclei (MN), damage of DNA, and chromosome aberrations (CAs), as determined 
by the comet assay. By assessing the concentration of PCE air levels, environmental monitoring of exposure was performed on personal breathing zone air samples obtained over two consecutive working days. Since the number of people in both groups of this study was very small, caution was required in interpreting the findings. Thus, there is a need for more studies into the genotoxic effects of the dry cleaning industry.

Besides, Macca et al. (2012) conducted a study in 40 dry cleaning shops with a total of 71 subjects. Throughout the work shift, personal diffusive samplers were used to monitor the environment. On Thursday evening at the end-of-shift and Friday morning pre-shift, biological monitoring was conducted by measuring PCE in urine and blood, as well as trichloroacetic acid (TCA) in urine. PCE exposure and PCE in blood at the end-of-shift $(\mathrm{r}=0.67)$ and pre-shift $(\mathrm{r}=0.70)$, and also PCE in urine at the end-of-shift $(\mathrm{r}=0.68)$, were found to have strong correlations. However, there was no correlation between pre-shift PCE and urinary TCA and exposure. Thus, it can be inferredfrom this analysis that PCE in urine at end-of-shift and PCE in blood at end-of-shift and pre-shift at the end of the workweek were the most accurate markers.

\section{DISCUSSION}

Based on six literatures that were critically appraised in this study, it is known that three literatures describe the biomonitoring of tetrachlorethylene exposure and three literatures discusse about the biomonitoring effects of tetrachlorethylene in the human body, especially workers. However, some limitations in this study should be considered. First, the sample size of these accumulated literatures was small enough. Second, the samples of workers mostly came from one industry, which was dry cleaning, so it was less varied.

The accumulated literatures in this study about biomonitoring of tetrachloroethylene exposure provide solid evidence supporting assessment of tetrachloroethylene level in urine, in blood and also in exhaled air. The American Conference of Governmental Industrial Hygienists (ACGIH) currently also recommends measuring PCE concentrations in end-exhaled air (PCEalv) and blood (PCEb) before starting a shift (ACGIH, 2021). Exhaled air is also suggested for use in tetrachloroethylene biomonitoring. Exhaled air sampling in occupational biological monitoring, in fact, involves simple practical sampling procedures and methodological analysis that can be performed in standard biomonitoring laboratories (Ziener and Braunsdorf, 2014). However, as compared to the urine samples collected to calculate the index previously proposed in dry cleaners, collecting alveolar air for PCEalv measurements is more complicated and sensitive (Modenese et al., 2019).

Tetrachloroethylene concentrations in exhaled air and blood are less variable than urinary concentrations of trichloroacetic acid (TCA) based on the metabolism and elimination of tetrachloroethylene. TCA is also a metabolite of other chlorinated solvents, such as trichloroethylene and 1,1,1-trichloroethane. Because of this reason, the measurement of TCAu levels is less specific and more variable than the measurement of exhaled air or blood tetrachloroethylene levels as a measure of tetrachloroethylene exposure (Safe Work Australia, 2020). Tetrachloroethylene in blood is the chosen biological index for monitoring exposures if recruitment is not difficult (McKernan et al., 2008). The concentration of tetrachloroethylene in endof-shift urine becomes an appropriate biological exposure index for assessing current exposure in dry cleaners. The process of collecting samples to assess the index is noninvasive and can be implemented properly at work. As opposed to tetrachloroethylene in blood, the scientific methods for analysis are relatively simple and not more complicated (Modenese et al., 2019).

The use of end-shift urine as a biomonitoring to evaluate tetrachloroethylene exposure in workers is also supported by Macca et al. (2012) in their research stating that the most trustworthy indicators for tetrachloroethylene exposure biomonitoring are tetrachloroethylene in end-of-shift urine and tetrachloroethylene in blood at end-of-shift and pre-shift at the end of the workweek compared to TCA in urine (end-of and pre-shift). The biological exposure limits for tetrachloroethylene in urine is $56 \mu \mathrm{g} / \mathrm{L}(0.056 \mathrm{mg} / \mathrm{L})$, tetrachloroethylene in blood is $0.4-0.5 \mathrm{mg} / \mathrm{L}$, tetrachloroethylene in exhaled air is $3 \mathrm{ppm}$ and TCA in urine is $3.5 \mathrm{mg} / \mathrm{L}$ (Macca et al., 2012). The problem is the biomonitoring of tetrachloroethylene exposure in Indonesia still very limited, so it is necessary to carry out another test which is more applicable to be implemented in Indonesia, like biomonitoring of tetrachloroethylene effects. 
Tetrachloroethylene is also likely to cause cancer in humans. Exposure to this substance is known to cause genetic defects (Guyton et al., 2014). The parameter that can be easily assessed in case of genetic damage is the micronucleus. The micronucleus is a biomarker that can be identified as a result of genotoxic substance exposure and is a signal of carcinogenesis' initial process. It is known that exposure to tetrachloroethylene can increase the micronucleus production in the buccal mucosal epithelium of dry cleaners. Dry cleaners are exposed to tetrachloroethylene by inhalation. Tetrachloroethylene particles emitted into the atmosphere from washing clothes penetrate the respiratory system and bind to the buccal mucosa, which serves as the first barrier to genotoxic material exposure (Julianti et al., 2019).

In addition, tetrachloroethylene contains genotoxic substances. Tetrachloroethylene is converted to reactive metabolites in the body by the cytochrome p-450 enzyme through an oxidation reaction and also glutathione conjugation (Guha et al., 2012; Guyton et al., 2014). These metabolites will reach the bloodstream and cause chromosome chains to break down, resulting in the formation of a new, smaller nucleus, which is separated from the main nucleus. A micronucleus is a type of abnormal cell that has a nucleus that is $1 / 3-1 / 6$ the size of a normal nucleus and is located next to it. The formation of the micronucleus happens because chromosomes are damaged during the mitosis process. The researchers chose to use the nucleus anomaly test from buccal mucosal epithelium because it is simpler to perform and less expensive than other studies. The measurement of micronuclei can be done in buccal mucosal epithelium and also in blood (erythrocyte and lymphocyte). The buccal cell $\mathrm{MN}$ assay at present becomes a promising tool for surveying workers exposed to genotoxic agents (Bolognesi et al., 2015; Hopf et al., 2019; Julianti et al., 2019).

Based on the study by Everatt et al. (2013), it is known that exposure to tetrachloroethylene below the permissible occupational exposure limit can increase the risk of genetic damage among drycleaning workers. Comet assay and micronucleus examinations on peripheral blood lymphocytes are useful for biological monitoring populations exposed to low-dose tetrachloroethylene. These examinations can be used as a biomonitoring of effect on tetrachloroethylene exposure. Based on the study by Azimi et al. (2017), it is also known that dry cleaners can be exposed to tetrachloroethylene in the workplace, which can cause DNA damage. The results of blood tests to assess DNA damage can be considered evidence of a potential genotoxic and carcinogenic effect of occupational tetrachloroethylene exposure.

The workplace exposure standard for tetrachloroethylene is time weighted average (TWA) of $25 \mathrm{ppm}$ and short term (15 minute time weighted average) exposure limit (STEL) of $100 \mathrm{ppm}$ (ACGIH, 2021). If air monitoring results suggest frequent or potentially high exposure, a physical and blood examination may be recommended (half of the TWA or above). Furthermore, if the results of the medical examination show that the workers have symptoms of tetrachloroethylene exposure, the company doctor should consider recommending that the worker be removed from job task related to tetrachloroethylene. When transfer of workers from jobs related to tetrachloroethylene is indicated, the doctor should provide the company with the following recommendations: 1) workers should be removed from work exposed to tetrachloroethylene, and 2) the company must review the control measures and implement the recommended corrective actions.

In addition, the company can carry out several controls for potential hazards found in the workplace based on a hierarchy of controls. First, the company should do an elimination. Elimination is the control measure that is the first choice for controlling exposure because it removes hazards from the workplace. However, some dangers are difficult to be completely removed from the workplace. The second step is substitution. Substitution is an effort to replace materials, tools or work methods with other alternatives with a lower hazard level so as to reduce the possibility of serious impacts. However, sometimes this is also difficult to be done in the workplace. Third, the company should do engineering control. Engineering control is carried out by changing the design of tools and/ or workplaces. Engineering control can be carried out by sludge scraping, filter cleaning, installation of a local exhaust ventilation system and tetrachloroethylene concentration control devices in this facility. Fourth, the company should do administrative control. Administrative controls serve to limit exposures to workers, for example training to raising worker awareness of the health effects of tetrachloroethylene and the value of wearing personal protective equipment (PPE) when 
performing their job. Storage of tetrachlorethylene must be properly maintained according to the regulations specified in the PERC Material Safety Data Sheet. In addition, it is necessary to set standard operating procedures related with good maintenance and leak detector for avoiding leak of Perc. The development of a safety culture among dry cleaners focusing on proper solvent handling and workplace sanitation can also help to prevent potential toxic effects from tetrachloroethylene exposure. Fifth, the use of PPE like mask and hand gloves should be used correctly (Manuele, 2005; Lucas et al., 2015; Azimi et al., 2017; Habib et al., 2018).

\section{CONCLUSION}

Exposure to tetrachloroethylene can cause health problems for workers, including the effects on central nervous system (CNS), eyes, liver, respiratory tract, skin and kidneys, as well as carcinogenic effects. The recommended exposure biomonitoring to detect tetrachloroethylene in the body is the examination of tetrachloroethylene levels in blood, urine and exhaled air. Biomonitoring methods of effect that can be implemented are the examination of micronucleus frequency $(\mathrm{MN})$ and DNA damage to assess genotoxic effects. Micronucleus frequency examination from the buccal mucosa becomes the simplest biomonitoring of effect to assess early signs of carcinogenesis and becomes biomonitoring that is more feasible to be implemented in Indonesia. Further studies with better quality are needed to provide stronger evidence regarding tetrachlorethylene biomonitoring in exposed workers.

\section{ACKNOWLEDGEMENTS}

The authors expresses great gratitude to dr. Nuri Purwito Adi, MKK, Sp.Ok as the Head of Occupational Medicine Specialist Program for the support and facilities during the accomplishment of this literature review.

\section{REFERENCES}

ACGIH (2021) 2021 TLVS and BEIs Based on the Documentation of the Threshold Limit Values for Chemical Substances and Physical Agents \& Biological Exposure Indices. Cincinnati: American Conference of Governmental Industrial Hygienists.
Azimi, M. et al. (2017) 'Primary DNA Damage in Dry Cleaners with Perchlorethylene Exposure', International Journal of Occupational and Environmental Medicine, 8(4), pp. 224-231.

Barton, C. (2014) Tetrachloroethylene, Encyclopedia of Toxicology: Third Edition. Waltham, MA: Academic Press.

Bolognesi, C. et al. (2015) 'Buccal Micronucleus Cytome Assay: Results of an Intra- and InterLaboratory Scoring Comparison', Mutagenesis, 30(4), pp. 545-555.

Cichocki, J. A. et al. (2016) 'Target Organ Metabolism, Toxicity, and Mechanisms of Trichloroethylene and Perchloroethylene: Key Similarities, Differences, and Data Gaps', Journal of Pharmacology and Experimental Therapeutics, 359(1), pp. 110-123.

Dias, C. M., Menezes, H. C. and Cardeal, Z. L. (2017) 'Use of Exhaled air as an Improved Biomonitoring Method to Assess Perchloroethylene Short-term Exposure', Environmental Research, 156, pp. 108-112.

Everatt, R. et al (2013) 'Biomonitoring Study of Dry Cleaning Workers using Cytogenetic Tests and the Comet Assay', Journal of Occupational and Environmental Hygiene, 10(11), pp. 609-621.

Gold, L. S.et al. (2008) 'Systematic Literature Review of uses and Levels of Occupational Exposure to Tetrachloroethylene', Journal of Occupational and Environmental Hygiene, 5(12), pp. $807-839$.

Guha, N. et al. (2012) 'Carcinogenicity of Trichloroethylene, Tetrachloroethylene, some other Chlorinated Solvents, and their Metabolites', The Lancet Oncology, 13(12), pp. 1192-1193.

Guyton, K. Z.et al (2014) 'Human Health Effects of Tetrachloroethylene: Key Findings and Scientific Issues', Environmental Health Perspectives, 122(4), pp. 325-334.

Habib, S. et al. (2018) 'Preliminary Study: Environmental Assessment of Perchloroethylene in Dry-Cleaning Facilities in the UAE', Journal of Environmental and Public Health, 2018, pp. $1-5$.

Hopf, N. B. et al. (2019) 'Biological Monitoring of Workers Exposed to Carcinogens using the buccal Micronucleus approach: A systematic review and Meta-analysis', Mutation Research - Reviews in Mutation Research, 781, pp. 11-29.

IARC (2014) Trichloroethylene, Tetrachloroethylene, and Some Other Chlorinated Agents, IARC Monographs on the Evaluation of Carcinogenic 
Risks to Humans. Lyon: The International Agency for Research on Cancer.

Julianti, R. R. et al. (2019) 'The Effect of Perchloroethylene (PCE) Exposure toward Frequency of Micronucleus Formation in Buccal Mucosal Ephitelia of Dry Cleaning Employees", Journal of Medicine (Bangladesh), 20(2), pp. 59-62.

Kawai, T., Sakurai, H. and Ikeda, M. (2018) 'Further Examination of Log $\mathrm{P}$ ow -based Procedures to Estimate Biological Occupational Exposure Limits', Journal of Occupational Health, 60(6), pp. 453-457.

Lucas, D. et al. (2015) 'Assessment of Exposure to Perchloroethylene and its Clinical Repercussions for 50 Dry-Cleaning Employees', Journal of Occupational and Environmental Hygiene, 12(11), pp. 767-773.

Macca, I. et al. (2012) 'Biological Monitoring of Exposure to Perchloroethylene in Dry Cleaning Workers', Medicina del Lavoro, 103(5), pp. 382-393.

Manuele, F. A. (2005) 'Risk Assessment and Hierarchies of Control', Profesional Safety, 50(May), pp. 33-39.

McKernan, L. T. et al. (2008) 'Biological Exposure Assessment to Tetrachloroethylene for Workers in the Dry Cleaning Industry', Environmental
Health: A Global Access Science Source, 7(12), pp. 1-10.

Modenese, A. et al. (2019) 'Evaluation of Occupational Exposure to Perchlorethylene in A Group of Italian Dry Cleaners using Noninvasive Exposure Indices', International Journal of Environmental Research and Public Health, 16(16), pp. 1-12.

OCEBM (2021) Critical Appraissal Tools. Oxford: Oxford Centre for Evidence based Medicine.

Safe Work Australia (2020) Health Monitoring Guide for Tetrachlorethylene. Canbera: Publishing Agency for Safe Work Australia.

Tucker, J. D. et al. (2011) 'Cytogenetic Analysis of an Exposed-Referent Study: PerchloroethyleneExposed Dry Cleaners Compared to Unexposed Laundry Workers', Environmental Health: A Global Access Science Source, 10(16), pp. 1-6.

Vlaanderen, J. et al. (2014) 'Tetrachloroethylene Exposure and Bladder Cancer Risk: A MetaAnalysis of Dry-Cleaning-Worker Studies', Environmental Health Perspectives, 122(7), pp. 661-666.

Ziener, C. E. and Braunsdorf, P. P. (2014) 'Trace Analysis in End-Exhaled Air using Direct solvent extraction in gas Sampling Tubes: Tetrachloroethene in Workers as an Example', International Journal of Analytical Chemistry, 3, pp. 1-10. 